\title{
Protein Synthesis by Day 16 Bovine Conceptuses during the Time of Maternal Recognition of Pregnancy
}

\author{
Irene Malo Estepa ${ }^{1}$, Haidee Tinning ${ }^{1}$, Elton Jóse Rosas Vasconcelos ${ }^{2}{ }^{\mathbb{D}}$, \\ Beatriz Fernandez-Fuertes ${ }^{3}{ }^{(}$, José María Sánchez ${ }^{4}{ }^{\circledR}$, Gregory W. Burns ${ }^{5}{ }^{\circledR}$, \\ Thomas E. Spencer ${ }^{5}$, Pat Lonergan 4 (i) and Niamh Forde ${ }^{1, *}$ \\ 1 Discovery and Translational Sciences Department, Leeds Institute of Cardiovascular and Metabolic \\ Medicine, Faculty of Medicine and Health, University of Leeds, West Yorkshire LS2 9JT, UK; \\ I.MaloEstepa@leeds.ac.uk (I.M.E.); bs13hghs@leeds.ac.uk (H.T.) \\ 2 Leeds Omics Virtual Research Institute, University of Leeds, West Yorkshire LS2 9JT, UK; \\ E.Vasconcelos@leeds.ac.uk \\ 3 Department of Biology, Faculty of Sciences, Institute of Food and Agricultural Technology, \\ University of Girona, 17003 Girona, Spain; bffuertes@gmail.com \\ 4 School of Agriculture and Food Science, University College Dublin, Belfield, Dublin 4, Ireland; \\ jovenpadawan5@hotmail.com (J.M.S.); pat.lonergan@ucd.ie (P.L.) \\ 5 Division of Animal Sciences, University of Missouri, Columbia, MO 65211, USA; \\ gbvd6@mail.missouri.edu (G.W.B.); spencerte@missouri.edu (T.E.S.) \\ * Correspondence: n.forde@leeds.ac.uk
}

Received: 5 March 2020; Accepted: 14 April 2020; Published: 20 April 2020 updates

\begin{abstract}
Interferon Tau (IFNT), the conceptus-derived pregnancy recognition signal in cattle, significantly modifies the transcriptome of the endometrium. However, the endometrium also responds to IFNT-independent conceptus-derived products. The aim of this study was to determine what proteins are produced by the bovine conceptus that may facilitate the pregnancy recognition process in cattle. We analysed by mass spectrometry the proteins present in conceptus-conditioned media (CCM) after 6 h culture of Day 16 bovine conceptuses $(n=8)$ in SILAC media (arginine- and lysine-depleted media supplemented with heavy isotopes) and the protein content of extracellular vesicles (EVs) isolated from uterine luminal fluid (ULF) of Day 16 pregnant $(n=7)$ and cyclic $(n=6)$ cross-bred heifers on day 16. In total, 11,122 proteins were identified in the CCM. Of these, 5.95\% (662) had peptides with heavy labelled amino acids, i.e., de novo synthesised by the conceptuses. None of these proteins were detected in the EVs isolated from ULF. Pregnancy-associated glycoprotein 11, Trophoblast Kunitz domain protein 1 and DExD-Box Helicase 39A were de novo produced and present in the CCM from all conceptuses and in previously published CCM data following 6 and $24 \mathrm{~h}$. A total of 463 proteins were present in the CCM from all the conceptuses in the present study, and after 6 and $24 \mathrm{~h}$ culture in a previous study, while expression of their transcripts was not detected in endometrium indicating that they are likely conceptus-derived. Of the proteins present in the EVs, 67 were uniquely identified in ULF from pregnant heifers; 35 of these had been previously reported in CCM from Day 16 conceptuses. This study has narrowed a set of conceptus-derived proteins that may be involved in EV-mediated IFNT-independent embryo-maternal communication during pregnancy recognition in cattle.
\end{abstract}

Keywords: endometrium; SILAC; pregnancy recognition; conceptus; extracellular vesicles; proteomics; bovine 


\section{Introduction}

Understanding the molecular communication that occurs between the developing conceptus (embryo and associated extraembryonic membranes) and the maternal endometrium is key to enhancing our understanding of early pregnancy loss in cattle. During early pregnancy, the embryo induces very localised changes at the transcriptional level in the oviduct [1,2] and in vitro coculture of embryos with oviductal cells accelerates blastocyst development and changes the epigenetic status of the embryos [2,3]. This indicates that interaction with the female reproductive tract, while not strictly necessary for early embryo development, enhances embryo quality [4]. More recently, local effects of the embryo on the endometrium at the blastocyst stage have been demonstrated [5-7]. Following hatching of the blastocyst from the zona pellucida, there begins a sequential modification to the transcriptome of the endometrium as early as Day 13 [8,9], which is amplified during the time of pregnancy recognition (Day 16) [10-12] This response is further propagated into extrauterine tissues, including the corpus luteum (CL) and peripheral blood [13-16]. These interactions are predominantly mediated by the pregnancy recognition signal Interferon Tau (IFNT), a type-I interferon produced by the trophectoderm cells which is required to inhibit luteolysis and maintain the CL. In addition to IFNT, which significantly modifies the transcriptome of the endometrium $[17,18]$, other proteins are produced by the conceptus $[19,20]$ coordinated with increased production of IFNT. Moreover, the response of the endometrium to the conceptus as a whole is greater than its response to prolonged exposure to a type I interferon for 3 days in vivo [12,18].

In addition to traditional receptor-ligand binding signaling between the endometrium and the conceptus, there is evidence for a role of extracellular vesicle (EV)-mediated communication between the conceptus and the endometrium in sheep [21,22] and cattle [23] during early pregnancy. The size, concentration, and content of EVs released by the embryo can be affected by environmental factors, such as oxidative stress, in an embryo sex-dependent manner [24]. This type of communication may also explain, in part, why a large proportion of uterine lumen fluid (ULF) proteins are not classically secreted in nature, i.e., not classed as ligands or extracellular proteins [19].

Studying the proteins (other than IFNT) that may mediate conceptus-maternal interaction is challenging for a number of reasons. Firstly, proteins that are present in the ULF around the time of pregnancy recognition may be derived from the conceptus itself or may be derived from the endometrium in response to the presence of the conceptus, or a combination of both [25]. Secondly, attempts to grow embryos past the blastocyst stage and artificially induce elongation in vitro have not been successful $[26,27]$ and therefore in vivo models are essential. We have previously characterized the proteins produced by the conceptus following culture in vitro for 6 and 24 h; however, which of these proteins are de novo synthesized as a response to the in vitro environment or facilitate conceptus-maternal interactions is not known [19].

One approach to the identification of de novo synthesized proteins is to use a technique known as stable isotope labelling by amino acids in cell culture (SILAC). This approach consists of heavy or light isotope-labelled amino acids that are added to cell culture media depleted of these specific amino acids. These heavy forms of amino acids then get incorporated during protein synthesis in vitro, i.e., they are de novo synthesized [28]. Because of the difference in mass of the peptides produced bearing the heavy forms of these amino acids, we can differentiate these via mass spectrometry. This allows the identification of de novo produced proteins, i.e., those containing the heavy isotope forms of amino acids in their peptide fragments [28]. This widely used technique has proven useful in the study of de novo produced proteins in vitro [29-32] and could bring novel insights into conceptus-derived proteins involved in pregnancy recognition.

The aim of the present study was to use this novel SILAC-based approach to identify de novo produced proteins by the Day 16 bovine conceptus and to determine if any of these proteins are present in the EVs derived from the ULF of pregnant heifers, which would support a role in conceptus-maternal interactions during pregnancy recognition. 


\section{Results}

\subsection{Experiment 1}

2.1.1. Proteins Present in Conceptus-Conditioned Media Following 6 h Culture of Day 16 Conceptuses In Vitro

Proteomic analysis of CCM identified 11,122 different proteins present in the media recovered from one or more conceptuses (numbers and percentages are shown in Table 1) that were not detected in the contemporaneous blanks. Of those, 1576 proteins $(14.2 \%)$ were identified in media from all eight conceptuses, 2757 (24.8\%) were present in media recovered from six or more conceptuses $(n \geq 6)$, and 3997 (36.0\%) proteins identified in media recovered from at least four of the conceptuses $(n \geq 4$; Supplementary Table S1). Six different isoforms of IFNT were detected in the CCM from different conceptuses (Supplementary Table S1). These were IFNT 1i, IFNT 1g, IFNT 3i, IFNT 3, IFNT 4a and IFNT c1. The only heavy labelled variant was IFNT variant $1 \mathrm{~g}$ in the CCM from conceptus "H". The rest of CCM presented one or more light labelled variants of IFNT.

Table 1. Number and percentage of the proteins present in CCM identified via nano-LC MS/MS proteomics of SILAC-labelled media minus Arginine and Lysine supplemented with heavy forms of these amino acids ( $n=8$ CCM: $n=3$ contemporaneous blanks) from Day 16 in vivo produced conceptuses after $6 \mathrm{~h}$ culture.

\begin{tabular}{cccccc}
\hline $\begin{array}{c}\text { Number of } \\
\text { Conceptuses }\end{array}$ & Proteins & \% of Total & $\begin{array}{c}\text { Heavy Labelled } \\
\text { Proteins }\end{array}$ & $\begin{array}{c}\text { \% Heavy Labelled } \\
\text { Proteins }\end{array}$ & $\begin{array}{c}\text { \% Heavy/Total } \\
\text { Proteins }\end{array}$ \\
\hline 8 & 1576 & 14.17 & 0 & 0 & 0 \\
\hline$\geq 7$ & 2180 & 19.60 & 0 & 0 & 0 \\
\hline 26 & 2757 & 24.79 & 0 & 0 & 0 \\
\hline$\geq 5$ & 3314 & 29.80 & 2 & 0.3 & 0.01 \\
\hline$\geq 4$ & 3997 & 35.94 & 3 & 1.36 & 0.02 \\
\hline$\geq 3$ & 4939 & 44.41 & 9 & 7.7 & 0.08 \\
\hline$\geq 2$ & 6680 & 60.06 & 51 & 100 & 0.46 \\
\hline 1 (total) & 11,122 & 100 & 662 & 5.49 \\
\hline
\end{tabular}

The 1576 proteins detected in CCM from all eight conceptuses were analyzed using DAVID to identify over-represented biological processes and pathways (Supplementary Table S2). The top 10 over-represented KEGG pathways of the 77 detected based on their fold enrichment were mainly related to metabolism (Table 2). Gene ontology (GO) term analysis for biological processes identified 492 over-represented terms, the details of which are provided in Supplementary Table S3.

\subsubsection{De Novo Proteins Synthesized by Day 16 Conceptuses Following Culture In Vitro}

A total of 662 proteins were identified as having peptide fragments containing heavy labelled amino acids (5.95\% of the total proteins, Table 1$)$. This is indicative of being de novo produced by the conceptuses in vitro as opposed to those light labelled, which were most likely produced prior to culture of the conceptuses in SILAC media. Proteins were heavy labelled to different extents depending on the sample analyzed. No protein containing heavy labelled amino acids was detected in CCM from all eight conceptuses (Table 3). THO complex subunit 7 homolog (THOC7) and RING finger protein 207 (RNF207), containing heavy labelled amino acids in their peptide fragments, were detected in CCM from five animals, with SET domain containing 9 (SETD9) detected in CCM from four animals. Six de novo produced proteins (MER proto-oncogene tyrosine kinase (MERTK); G protein-coupled receptor class $C$ group 5 member A (GPRC5A); DExH-box helicase 34 (DHX34); Disco interacting protein 2 homolog A (DIP2A); MAGE domain-containing protein (MAGED1); and OTU deubiquitinase 
6A (OTUD6A)) were identified in media from three conceptuses, and a total of 42 proteins with heavy labelled amino acids in their peptides were de novo produced by two conceptuses (Table 1). A total of 611 proteins with heavy labelled amino acids were present in the CCM from one conceptus (Supplementary Table S1). Three proteins, MERTK, and Poly (ADP-ribose) polymerase (TNKS2) and Trophoblast Kunitz domain protein 1 (TKDP1), were detected in CCM in all eight samples; however, heavy labelled versions of these proteins were only detected in two samples. Those proteins that were identified in CCM of more than three conceptuses that contained a heavy labelled peptide fragment are presented in Table 3.

Table 2. Top 10 overrepresented pathways from 1576 proteins identified in the in conceptus-conditioned media $(\mathrm{CCM})(n=8)$ from all the conceptuses via nano-LC MS/MS proteomic analysis of SILAC-labelled media (minus Arginine and Lysine supplemented with heavy forms of these amino acids: $n=8 \mathrm{CCM}$, $n=3$ contemporaneous blanks) from Day 16 in vivo produced conceptuses after $6 \mathrm{~h}$ culture.

\begin{tabular}{|c|c|c|c|c|c|c|c|}
\hline GO Terms & Count & $\%$ & $p$ Value & $\begin{array}{c}\text { List } \\
\text { Total }\end{array}$ & $\begin{array}{l}\text { Pop } \\
\text { Hits }\end{array}$ & $\begin{array}{l}\text { Pop } \\
\text { Total }\end{array}$ & $\begin{array}{c}\text { Fold } \\
\text { Enrichment }\end{array}$ \\
\hline Proteasome & 31 & 2.032787 & $3.80 \times 10^{-17}$ & 926 & 46 & 7550 & 5.494647 \\
\hline Citrate cycle (TCA cycle) & 17 & 1.114754 & $6.21 \times 10^{-8}$ & 926 & 30 & 7550 & 4.62023 \\
\hline Pyruvate metabolism & 21 & 1.377049 & $1.83 \times 10^{-9}$ & 926 & 38 & 7550 & 4.505797 \\
\hline Other glycan degradation & 11 & 0.721311 & $4.21 \times 10^{-5}$ & 926 & 20 & 7550 & 4.484341 \\
\hline Propanoate metabolism & 14 & 0.918033 & $2.89 \times 10^{-6}$ & 926 & 26 & 7550 & 4.390264 \\
\hline Carbon metabolism & 55 & 3.606557 & $7.77 \times 10^{-22}$ & 926 & 109 & 7550 & 4.114075 \\
\hline $\begin{array}{l}\text { Amino sugar and nucleotide } \\
\text { sugar metabolism }\end{array}$ & 24 & 1.57377 & $1.23 \times 10^{-9}$ & 926 & 48 & 7550 & 4.076674 \\
\hline 2-Oxocarboxylic acid metabolism & 9 & 0.590164 & $6.95 \times 10^{-4}$ & 926 & 18 & 7550 & 4.076674 \\
\hline Sulfur metabolism & 5 & 0.327869 & 0.025586 & 926 & 10 & 7550 & 4.076674 \\
\hline $\begin{array}{l}\text { Glyoxylate and dicarboxylate } \\
\text { metabolism }\end{array}$ & 12 & 0.786885 & $1.18 \times 10^{-4}$ & 926 & 26 & 7550 & 3.763084 \\
\hline
\end{tabular}

Table 3. Proteins present in CCM identified via nano-LC MS/MS proteomics of SILAC-labelled media minus Arginine and Lysine supplemented with heavy forms of these amino acids ( $n=8$ CCM: $n=3$ contemporaneous blanks) from Day 16 in vivo produced conceptuses after $6 \mathrm{~h}$ culture with heavy isotopes $(\mathrm{H})$ in three or more CCM $(\mathrm{B}-\mathrm{J})$, and their presence as light $(\mathrm{L})$ isotopes or absence (" 0 "). The total of CCM presenting heavy (Count $\mathrm{H}$ labelled) or light isotopes (Count L labelled) is added up for each protein under Total count. The Protein ID corresponds to uniport.org.

\begin{tabular}{|c|c|c|c|c|c|c|c|c|c|c|c|c|c|}
\hline Protein & $\begin{array}{l}\text { Protein } \\
\text { Name }\end{array}$ & $\begin{array}{l}\text { Protein } \\
\text { ID }\end{array}$ & B & C & D & $\mathbf{E}$ & $\mathbf{F}$ & $\mathbf{H}$ & $\mathbf{I}$ & $\mathbf{J}$ & $\begin{array}{l}\text { Count } \mathbf{H} \\
\text { Labelled }\end{array}$ & $\begin{array}{l}\text { Count L } \\
\text { Labelled }\end{array}$ & $\begin{array}{l}\text { Total } \\
\text { Count }\end{array}$ \\
\hline $\begin{array}{l}\text { THO complex subunit } 7 \\
\text { homolog }\end{array}$ & THOC7 & F1MSQ1 & $\mathrm{H}$ & $\mathrm{H}$ & $\mathrm{L}$ & $\mathrm{H}$ & 0 & 0 & $\mathrm{H}$ & $\mathrm{H}$ & 5 & 1 & 6 \\
\hline RING finger protein 207 & RNF207 & A0JNG4 & $\mathrm{H}$ & $\mathrm{H}$ & $\mathrm{H}$ & 0 & $\mathrm{H}$ & 0 & $\mathrm{H}$ & 0 & 5 & 0 & 5 \\
\hline SET domain containing 9 & SETD9 & F1MWB0 & $\mathrm{H}$ & $\mathrm{H}$ & $\mathrm{H}$ & $\mathrm{L}$ & $\mathrm{L}$ & $\mathrm{H}$ & $\mathrm{L}$ & 0 & 4 & 3 & 7 \\
\hline $\begin{array}{l}\text { MER proto-oncogene, } \\
\text { tyrosine kinase }\end{array}$ & MERTK & F1N381 & $\mathrm{H}$ & $\mathrm{L}$ & $\mathrm{H}$ & $\mathrm{L}$ & $\mathrm{L}$ & $\mathrm{H}$ & $\mathrm{L}$ & $\mathrm{L}$ & 3 & 5 & 8 \\
\hline $\begin{array}{l}\text { G protein-coupled receptor class } \\
\text { C group } 5 \text { member A }\end{array}$ & GPRC5A & F1N6N2 & $\mathrm{H}$ & $\mathrm{H}$ & 0 & $\mathrm{~L}$ & $\mathrm{~L}$ & $\mathrm{H}$ & 0 & 0 & 3 & 2 & 5 \\
\hline DExH-box helicase 34 & DHX34 & E1BJ90 & 0 & $\mathrm{H}$ & $\mathrm{H}$ & 0 & 0 & 0 & $\mathrm{H}$ & 0 & 3 & 0 & 3 \\
\hline $\begin{array}{c}\text { Disco interacting protein } 2 \\
\text { homolog A }\end{array}$ & DIP2A & F1MPW1 & 0 & 0 & 0 & $\mathrm{H}$ & 0 & 0 & $\mathrm{H}$ & $\mathrm{H}$ & 3 & 0 & 3 \\
\hline Uncharacterized protein & & G3X6J6 & $\mathrm{H}$ & 0 & 0 & $\mathrm{H}$ & 0 & 0 & $\mathrm{H}$ & 0 & 3 & 0 & 3 \\
\hline OTU deubiquitinase $6 \mathrm{~A}$ & OTUD6A & G5E596 & $\mathrm{H}$ & 0 & $\mathrm{H}$ & 0 & 0 & 0 & $\mathrm{H}$ & 0 & 3 & 0 & 3 \\
\hline
\end{tabular}

Analysis of those proteins that contained peptides with heavy labelled amino acids revealed KEGG pathway over-representation of four pathways related to secretion and steroidogenesis (Table 4). 
No GO terms were over-represented (Supplementary Table S4). For the 26 proteins heavy labelled to a different extent (i.e., heavy labelled in one or more (CM) and present in the media from all eight conceptuses, no specific KEGG pathways or GO terms were identified as over-represented, likely due to the short list of proteins.

Table 4. Over-represented pathways in the subset of heavy labelled proteins present in the CCM from two or more conceptuses via nano-LC MSMS proteomics of SILAC-labelled media minus Arginine and Lysine supplemented with heavy forms of these amino acids ( $n=8 \mathrm{CCM}, n=3$ contemporaneous blanks) from Day 16 in vivo produced conceptuses after $6 \mathrm{~h}$ culture.

\begin{tabular}{cccccccc}
\hline KEGG Pathway & Count & $\%$ & $p$ Value & $\begin{array}{c}\text { List } \\
\text { Total }\end{array}$ & $\begin{array}{c}\text { Pop } \\
\text { Hits }\end{array}$ & $\begin{array}{c}\text { Pop } \\
\text { Total }\end{array}$ & $\begin{array}{c}\text { Fold } \\
\text { Enrichment }\end{array}$ \\
\hline Bile secretion & 3 & 6.818182 & 0.006783 & 15 & 68 & 7550 & 22.20588 \\
\hline $\begin{array}{c}\text { Aldosterone synthesis } \\
\text { and secretion }\end{array}$ & 3 & 6.818182 & 0.009068 & 15 & 79 & 7550 & 19.11392 \\
\hline Salivary secretion & 3 & 6.818182 & 0.009973 & 15 & 83 & 7550 & 18.19277 \\
\hline $\begin{array}{c}\text { Ovarian } \\
\text { steroidogenesis }\end{array}$ & 2 & 4.545455 & 0.088901 & 15 & 50 & 7550 & 20.13333 \\
\hline
\end{tabular}

\subsection{Experiment 2}

2.2.1. Specific Proteins are Unique to Extracellular Vesicles Recovered from Uterine Luminal Fluid of Pregnant Heifers on Day 16

The analysis of EVs isolated from ULF of confirmed pregnant and cyclic heifers in Experiment 2 had a mean $( \pm \mathrm{sd})$ diameter of $135 \mathrm{~nm}( \pm 15.8 \mathrm{~nm})$ with a range of $111-162 \mathrm{~nm}$. The average concentration of EVs was $1.13 \times 10^{12}$ particles $/ \mathrm{mL}$ (Table 5 ). In total, 324 proteins were identified with high confidence, i.e., $99 \%$ identity and with at least two spectral counts per protein (Supplementary Table S5). All data were filtered to identify those proteins present in the ULF of at least four of six heifers (for the pregnant group) and four of five heifers (in the cyclic group). A total of 301 and 256 proteins were identified in EVs recovered from the ULF of pregnant and cyclic heifers, respectively. Of these proteins, 232 were common to both groups, while 67 and 22 were unique to pregnant and cyclic ULF, respectively (Figure 1). Of the 67 proteins only identified in pregnant ULF, 35 were previously detected in CCM following short-term culture of Day 16 conceptuses, while ten of the 22 proteins detected in cyclic EVs were also detected in CCM [19].

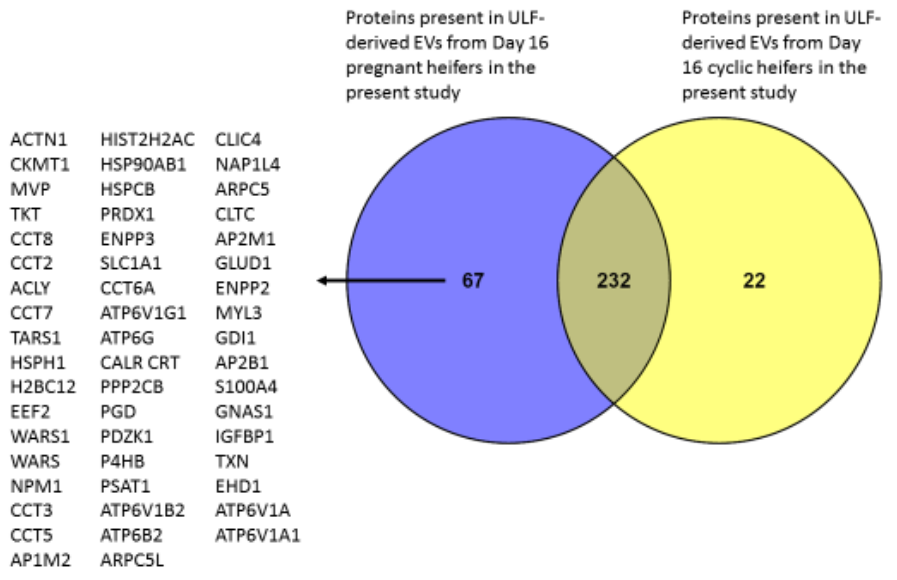

Figure 1. Venn diagram of the proteins present in extracellular vesicles (EVs) from the uterine luminal fluid (ULF) via nano-LC MSMS proteomics from Day 16 pregnant $(n=6)$ and cyclic $(n=5)$ heifers. Differences were identified between pregnant (Preg Day16 EVs) and cyclic (Cyc Day 16 EVs). 
Table 5. Concentration, mean and mode of the Extracellular Vesicles from ULF of Day 16 pregnant and cyclic heifers via NanoSight analysis.

\begin{tabular}{cccc}
\hline Group & $\begin{array}{c}\text { Concentration } \\
\text { (Particles/mL) }\end{array}$ & $\begin{array}{c}\text { Mean } \\
\text { Diameter (nm) }\end{array}$ & $\begin{array}{c}\text { Mode } \\
\text { Diameter (nm) }\end{array}$ \\
\hline Pregnant Day 16 Heifer 1 & $1.25 \times 10^{12}$ & 128.7 & 99.1 \\
\hline Pregnant Day 16 Heifer 2 & $3.16 \times 10^{11}$ & 98.1 & 95.4 \\
\hline Pregnant Day 16 Heifer 3 & $1.04 \times 10^{12}$ & 127.4 & 92.4 \\
\hline Pregnant Day 16 Heifer 4 & $6.01 \times 10^{11}$ & 111.2 & 91.6 \\
\hline Pregnant Day 16 Heifer 5 & $1.91 \times 10^{12}$ & 138.5 & 106.7 \\
\hline Pregnant Day 16 Heifer 6 & $1.32 \times 10^{12}$ & 138.8 & 106.7 \\
\hline Pregnant Day 16 Heifer 7 & $1.63 \times 10^{12}$ & 141.5 & 100.0 \\
\hline Cyclic Day 16 Heifer 1 & $2.86 \times 10^{11}$ & 115.2 & 92.1 \\
\hline Cyclic Day 16 Heifer 2 & $1.34 \times 10^{12}$ & 146.7 & 103.3 \\
\hline Cyclic Day 16 Heifer 3 & $2.04 \times 10^{12}$ & 151.1 & 108.8 \\
\hline Cyclic Day 16 Heifer 4 & $9.01 \times 10^{11}$ & 123.4 & 100.0 \\
\hline Cyclic Day 16 Heifer 5 & $1.05 \times 10^{12}$ & 162.0 & 113.3 \\
\hline Cyclic Day 16 Heifer 6 & $1.05 \times 10^{12}$ & 111.4 & 101.8 \\
\hline
\end{tabular}

The 67 proteins present exclusively in the EVs from ULF of pregnant heifers were submitted for KEGG pathway enrichment analysis. This revealed 11 over-represented pathways (Supplementary Table S6) involved in order by fold enrichment (Table 6) collecting duct acid secretion, synaptic vesicle cycle, endocrine and other factor-regulated calcium reabsorption, tight junction, rheumatoid arthritis, systemic lupus erythematosus, carbon metabolism, phagosome, endocytosis, protein processing in endoplasmic reticulum, and biosynthesis of antibiotics. The 10 most over-represented GO terms of 28 biological processes were mainly related to protein production and chromosomal alignment, with details provided in Supplementary Table S7.

Table 6. Eleven over-represented pathways of 67 proteins only present in the EVs from ULF in Day 16 pregnant heifers $(n=6)$ compared to cyclic heifers $(n=5)$ via nano-LC MS/MS proteomics.

\begin{tabular}{cccccccc}
\hline KEGG Pathway & Count & $\%$ & $p$ Value & $\begin{array}{c}\text { List } \\
\text { Total }\end{array}$ & $\begin{array}{c}\text { Pop } \\
\text { Hits }\end{array}$ & $\begin{array}{c}\text { Pop } \\
\text { Total }\end{array}$ & $\begin{array}{c}\text { Fold } \\
\text { Enrichment }\end{array}$ \\
\hline $\begin{array}{c}\text { Collecting duct acid } \\
\text { secretion }\end{array}$ & 3 & 5.172414 & $7.59 \times 10^{-3}$ & 38 & 27 & 7550 & 22.07602 \\
\hline $\begin{array}{c}\text { Synaptic vesicle cycle } \\
\text { Endocrine and other } \\
\text { factor-regulated } \\
\text { calcium reabsorption }\end{array}$ & 3 & 10.34483 & $1.22 \times 10^{-5}$ & 38 & 63 & 7550 & 18.92231 \\
\hline $\begin{array}{c}\text { Tight junction } \\
\text { Rheumatoid arthritis }\end{array}$ & 3 & 5.172414 & $1.78 \times 10^{-2}$ & 38 & 42 & 7550 & 14.19173 \\
\hline $\begin{array}{c}\text { Systemic lupus } \\
\text { erythematosus }\end{array}$ & 5 & 5.172414 & 0.078554 & 38 & 95 & 7550 & 6.274238 \\
\hline $\begin{array}{c}\text { Carbon metabolism } \\
\text { Phagosome }\end{array}$ & 3 & 5.172414 & 0.099294 & 38 & 109 & 7550 & 5.468373 \\
\hline Endocytosis & 6 & 10.34483 & $6.23 \times 10^{-3}$ & 38 & 243 & 7550 & 4.905783 \\
\hline $\begin{array}{c}\text { Protein processing in } \\
\text { endoplasmic reticulum }\end{array}$ & 4 & 6.896552 & 0.049135 & 38 & 169 & 7550 & 4.702585 \\
\hline $\begin{array}{c}\text { Biosynthesis of } \\
\text { antibiotics }\end{array}$ & 4 & 6.896552 & 0.079032 & 38 & 206 & 7550 & 3.857946 \\
\hline
\end{tabular}




\subsubsection{Comparison between Conceptus-Derived Proteins and Those Present in the EVs from ULF}

The GI identifiers of all proteins from EVs (Experiment 2) were converted to UniProt accession IDs using the retrieve/ID mapping tool from Uniprot.org in order to allow comparison of those present in EVs recovered from ULF of cyclic and pregnant heifers on Day 16 to those present in CCM from the current study (Experiment 1; Figure 2). After Uniprot conversion, 212 and 180 proteins were retrieved as present in EVs from the ULF of pregnant and cyclic heifers, respectively. Venn diagram analysis identified 108 proteins that were common to CCM and EVs derived from ULF of both pregnant and cyclic animals. Thirty proteins were present in CCM and EVs derived from ULF from pregnant heifers. In contrast, only 10 proteins were common between CCM and EVs derived from ULF of cyclic animals (Figure 2). Heavy proteins were only present in CCM and only 26 of them were actually present in the media from all the eight conceptuses. No overlap in proteins with heavy labelled amino acids was present in the EVs from the ULF.

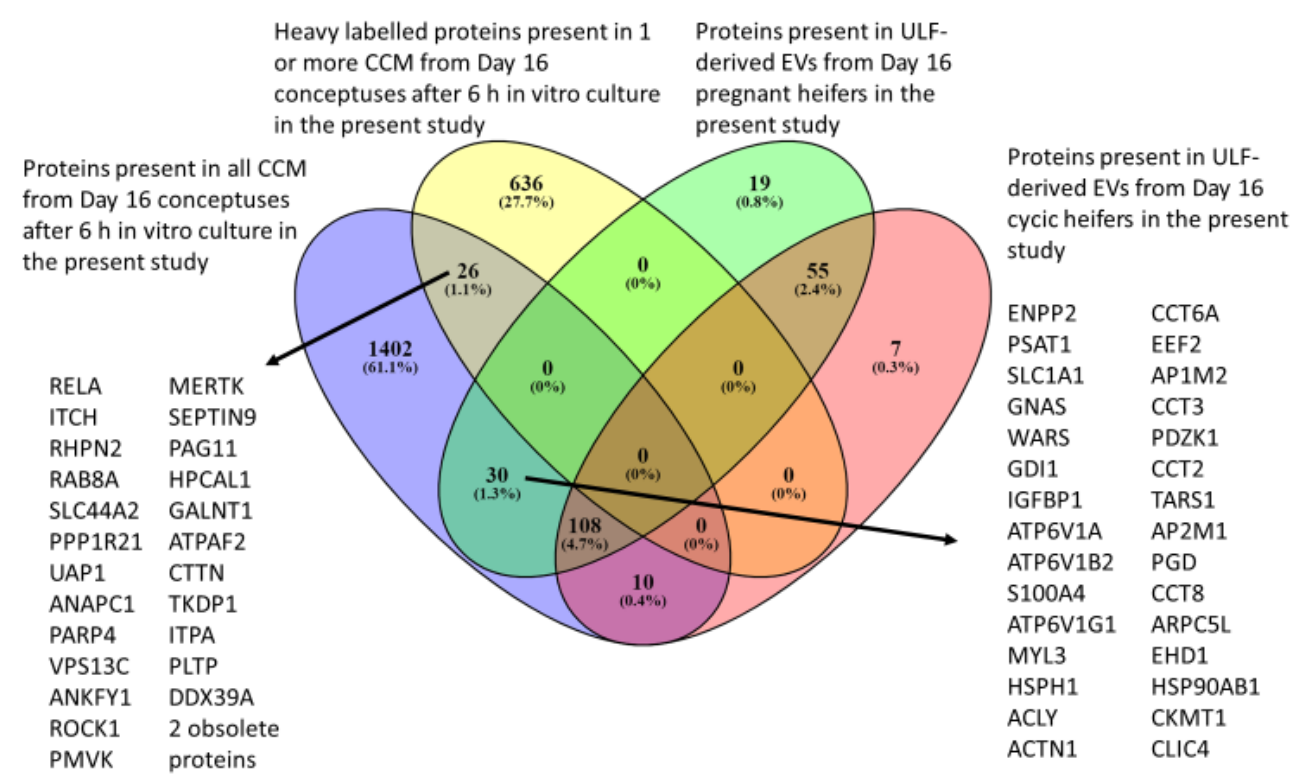

Figure 2. Venn diagram of the proteins present in CCM via nano-LC MSMS proteomics of SILAC-labelled media minus Arginine and Lysine supplemented with heavy forms of these amino acids ( $n=8 \mathrm{CCM}$, $n=3$ contemporaneous blanks) from Day 16 in vivo produced conceptuses after $6 \mathrm{~h}$ culture, and the proteins present in EVs from ULF via nano-LC MSMS proteomics from Day 16 pregnant and cyclic heifers.

\subsection{Comparison with Previous Studies}

\subsubsection{Comparison between Conceptus-Derived Proteins and Previously Published Work on CCM}

The proteins (total and heavy labelled) detected in the CCM from all eight conceptuses in the current study were compared to those detected in CCM after 6 and $24 \mathrm{~h}$ culture in non-SILAC media in our previous study (Figure 3) [19]. Only six heavy labelled proteins were detected in the previous study. Pregnancy associated protein 11 (PAG11), DEAD (Asp-Glu-Ala-Asp) box polypeptide 39 isoform 1 (DDX39) and TKDP1 were heavy labelled to different extents and present in the CCM from all the eight conceptuses in the present study and also in CCM after 6 and $24 \mathrm{~h}$ culture. Cortactin (CTTN) was present in the CCM from all conceptuses in the present study, was heavy labelled and also present in CCM after $24 \mathrm{~h}$ culture in the previous study. Two other proteins, Acyl-coenzyme A thioesterase (THEM4) and an uncharacterized protein (ENSBTAG00000046623), were heavy labelled to different extents in the present study and also present in CCM after 6 and $24 \mathrm{~h}$ culture of Day 16 conceptuses in the previous study, THEM4 was present in only seven of the eight CCM in the present study. 


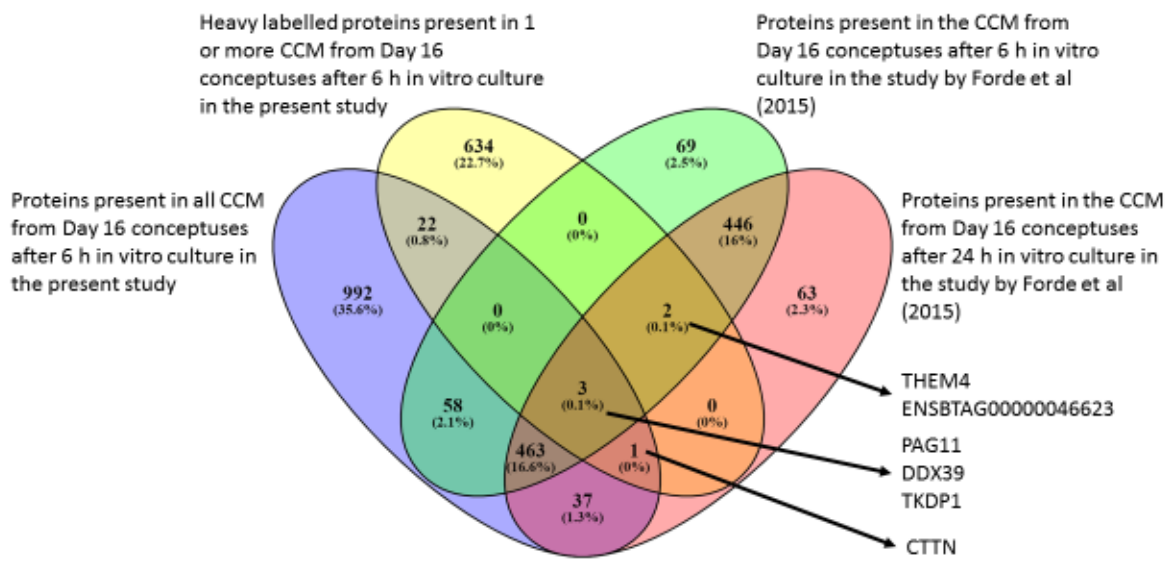

Figure 3. Venn diagram of the proteins present in CCM via nano-LC MSMS proteomics of SILAC-labelled media minus Arginine and Lysine supplemented with heavy forms of these amino acids ( $n=8$ CCM; $n=3$ contemporaneous blanks) from Day 16 in vivo produced conceptuses after $6 \mathrm{~h}$ culture. Differences were identified between All CCM determined proteins, those incorporated with Heavy labelled amino acids and previously reported data in the literature following 6 or $24 \mathrm{~h}$ culture [19].

A group of 463 proteins present in CCM from all the eight conceptuses in the current study did not have peptides with heavy labelled amino acids, and were also identified in CCM following 6 and $24 \mathrm{~h}$ culture in a previous study [19]. These 463 proteins were subjected to KEGG pathway analysis (Table 7) [33,34] and GO term analysis [35-37]. Thirty pathways were over-represented in this group (Supplementary Table S8). A total of 297 GO biological terms were over-represented (Supplementary Table S9), mainly related to chromosome alignment. None of the transcripts coding for these 463 proteins were detected in the endometrium in a previous study [9], indicating that they are likely of conceptus origin in ULF.

Table 7. Top 10 of 30 over-represented pathways of the 463 proteins present in the CCM from all the conceptuses via nano-LC MSMS proteomics of SILAC-labelled media minus Arginine and Lysine supplemented with heavy forms of these amino acids ( $n=8 \mathrm{CCM}, n=3$ contemporaneous blanks) from Day 16 in vivo produced conceptuses after $6 \mathrm{~h}$ culture, and previously reported proteins present in CCM from Day 16 in vivo produced conceptuses after 6 and $24 \mathrm{~h}$ culture [19].

\begin{tabular}{|c|c|c|c|c|c|c|c|}
\hline KEGG Pathway & Count & $\%$ & $p$ Value & $\begin{array}{c}\text { List } \\
\text { Total }\end{array}$ & $\begin{array}{l}\text { Pop } \\
\text { Hits }\end{array}$ & $\begin{array}{l}\text { Pop } \\
\text { Total }\end{array}$ & $\begin{array}{c}\text { Fold } \\
\text { Enrichment }\end{array}$ \\
\hline $\begin{array}{l}\text { Glyoxylate and } \\
\text { dicarboxylate } \\
\text { metabolism }\end{array}$ & 9 & 1.978022 & $6.96 \times 10^{-6}$ & 317 & 26 & 7550 & 8.244358 \\
\hline Proteasome & 15 & 3.296703 & $2.71 \times 10^{-9}$ & 317 & 46 & 7550 & 7.766424 \\
\hline $\begin{array}{l}\text { Other glycan } \\
\text { degradation }\end{array}$ & 6 & 1.318681 & 0.001147 & 317 & 20 & 7550 & 7.14511 \\
\hline $\begin{array}{c}\text { Pentose phosphate } \\
\text { pathway }\end{array}$ & 8 & 1.758242 & $9.06 \times 10^{-5}$ & 317 & 27 & 7550 & 7.056899 \\
\hline $\begin{array}{l}\text { 2-Oxocarboxylic acid } \\
\text { metabolism }\end{array}$ & 5 & 1.098901 & 0.005782 & 317 & 18 & 7550 & 6.615843 \\
\hline Ribosome & 36 & 7.912088 & $4.09 \times 10^{-19}$ & 317 & 134 & 7550 & 6.398606 \\
\hline $\begin{array}{l}\text { Biosynthesis of amino } \\
\text { acids }\end{array}$ & 19 & 4.175824 & $3.97 \times 10^{-10}$ & 317 & 71 & 7550 & 6.373573 \\
\hline $\begin{array}{l}\text { Citrate cycle } \\
\text { (TCA cycle) }\end{array}$ & 8 & 1.758242 & $1.86 \times 10^{-4}$ & 317 & 30 & 7550 & 6.351209 \\
\hline $\begin{array}{c}\text { Cysteine and } \\
\text { methionine metabolism }\end{array}$ & 10 & 2.197802 & $1.96 \times 10^{-5}$ & 317 & 38 & 7550 & 6.267641 \\
\hline $\begin{array}{c}\text { Glycosaminoglycan } \\
\text { degradation }\end{array}$ & 6 & 1.318681 & 0.002246 & 317 & 23 & 7550 & 6.213139 \\
\hline
\end{tabular}


The subset of 463 proteins present in the CCM from all the conceptuses in this study and detected following 6 and $24 \mathrm{~h}$ culture in a previous study [19] were compared to those only present in the EVs from ULF of Day 16 pregnant heifers (49 proteins) and there was an overlap of 20 proteins (Figure 4). These 463 proteins were also compared to the proteins detected in EVs from CCM after $24 \mathrm{~h}$ Day 14 ovine conceptuses in vitro culture (Figure 5). A total of 39 proteins were common between both species.

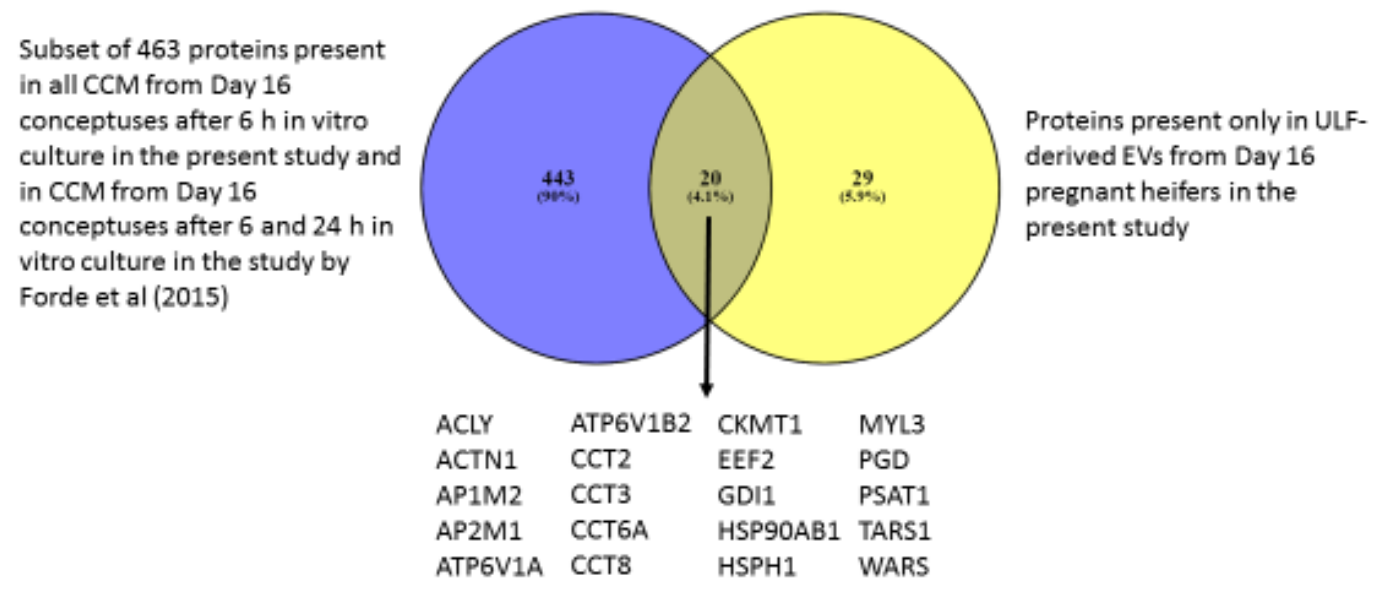

Figure 4. Venn diagram of the subset of 463 proteins identified via nano-LC MSMS proteomics in the CCM of Day 16 pregnant heifers after $6 \mathrm{~h}$ of culture and present after 6 and $24 \mathrm{~h}$ culture in a previous study [19] compared to those present in EVs from ULF of Day 16 pregnant heifers only.

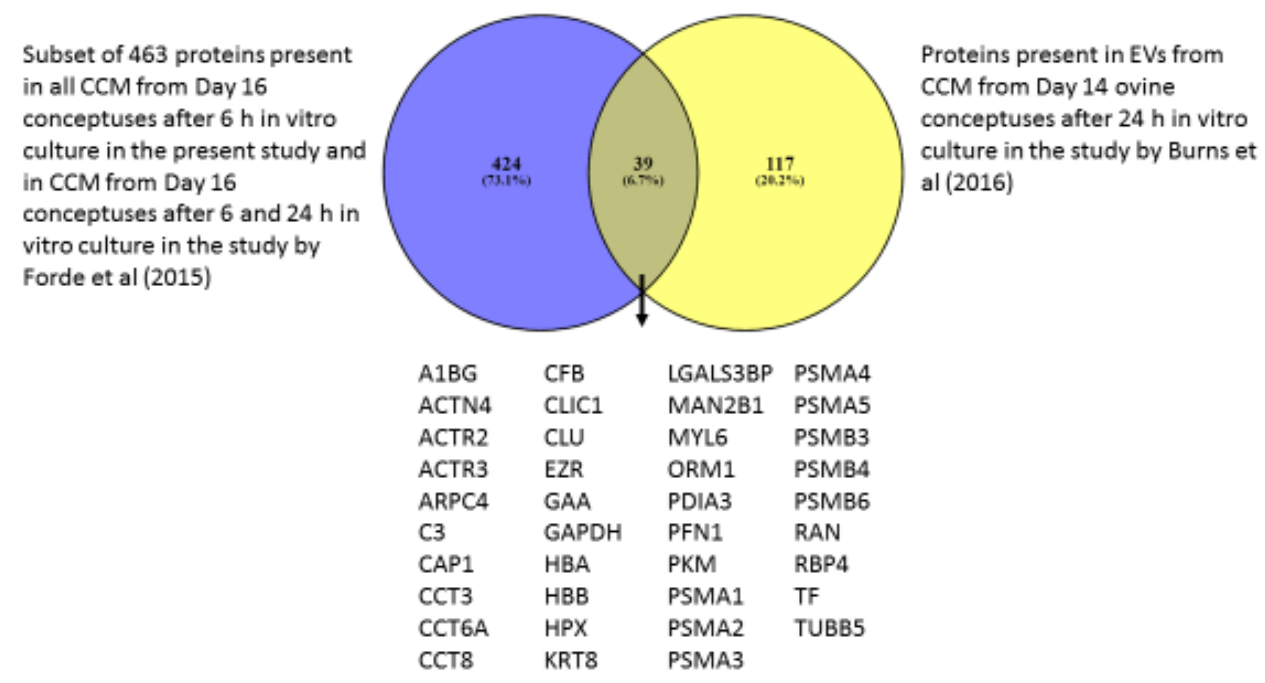

Figure 5. Venn diagram of the subset of 463 proteins identified via nano-LC MSMS proteomics in the CCM of Day 16 pregnant heifers after $6 \mathrm{~h}$ of culture and present after 6 and $24 \mathrm{~h}$ culture in a previous study [19] compared to those present in EVs from CCM of Day 14 pregnant ewes after $24 \mathrm{~h}$ in vitro culture [38].

2.3.2. Comparison of EV Components to Protein Composition of ULF from Previously Published Studies

The proteins present in the EVs from ULF of pregnant (301) and cyclic (256) heifers identified in the present study were compared to those previously identified in ULF on Day 16 of pregnancy in heifers not subjected to EV isolation [19,25]. Three proteins (CD48 molecule, tubulin alpha-1D chain, TUBA1D, and WAP four-disulfide core domain 2, WFDC2) were present in all groups, independent of EV enrichment or pregnancy status. Furthermore, 24 proteins were present in EVs from pregnant and cyclic heifers, as well as in ULF from Forde, McGettigan [25]. Finally, three proteins (TKT protein, 
amino acid transporter, SLC1A1, and Clathrin heavy chain 1, CLTC) were present in EVs from pregnant heifers and ULF from Forde, McGettigan [25]. These data are presented in Figure 6.

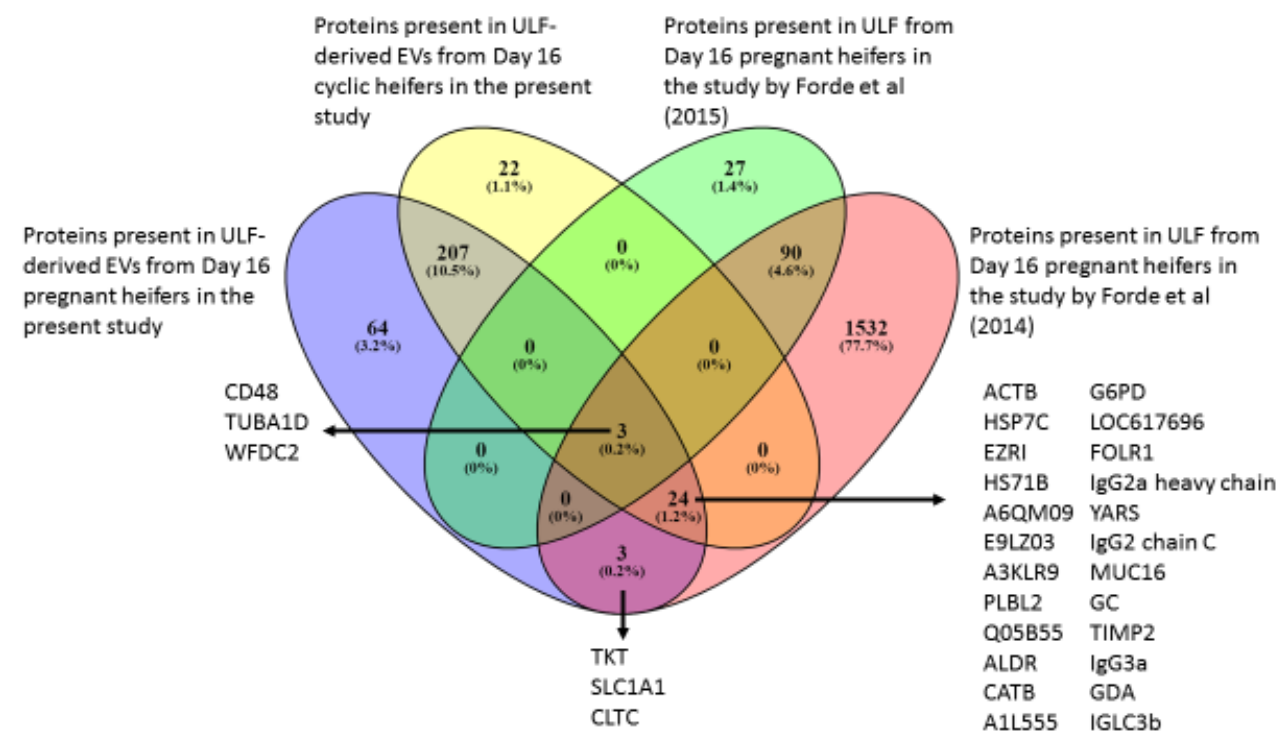

Figure 6. Venn diagram of the proteins present in EVs from ULF via nano-LC MSMS proteomics from Day 16 pregnant and cyclic heifers. Differences were identified between pregnant (ULF-P, $n=6$ ), cyclic (ULF-C, $n=5$ ) and previously reported data in clarified ULF from Day 16 pregnant heifers $[19,25]$.

\section{Discussion}

Understanding the signaling that occurs between the conceptus and the endometrium during maternal recognition of pregnancy is complex, particularly when investigating the role of conceptus-derived proteins other than IFNT. Understanding what proteins are produced and which of these are involved in EV-mediated interaction is complex due to the numerous sources of Day 16 proteins in ULF in vivo and the limitations around conceptus culture in vitro. To attempt to address this, we used a SILAC-labelled media approach to try to identify de novo produced proteins (and possibly a consequence of the in vitro environment) and those that are produced by the conceptus that may induce IFNT-independent responses in the endometrium. We also sought to determine if any of these are components of EVs present in the ULF of pregnant heifers.

Using a SILAC approach, only a small proportion of the proteins detected were de novo produced $(5.95 \%)$ by conceptuses following short-term culture in vitro, but these did display over-representation of secretory activity following pathway analysis. In a separate experiment, we also examined the protein components of EVs isolated from ULF of pregnant and cyclic heifers on Day 16. ULF-derived EVs have been demonstrated to be involved in embryo-maternal communication [21,39,40]; however, the difficulty of identifying conceptus-specific EVs lies in their dual origin as they can either be maternally or conceptus-derived. Surprisingly, no de novo synthesized proteins from the CCM were present in the EVs recovered from ULF. The enriched pathways were mainly related to protein production, including endocytosis. Fructose and mannose metabolism were also highlighted, which could be related to the metabolic demands of the developing conceptus. The GO terms also highlighted endocytosis and protein production, but some other processes related to telomerase activity and regulation of telomeres were also over-represented.

\subsection{De Novo Synthesised Proteins in Conceptus-Conditioned Media}

A relatively low proportion of proteins (5.95\% of total proteins identified, Table 1$)$ were identified as containing de novo produced peptides in CCM, i.e., contained heavy labelled amino acids and therefore were produced in vitro. We did identify six different variants of IFNT in the CCM, although 
only one was heavy labelled in CCM from one conceptus. There was also considerable variation between conceptuses in terms of the proteins produced, and most heavy labelled proteins were de novo produced by one conceptus (277 proteins). Similarly, the proportion of light amino acid labelled proteins present in the CCM are predominantly from one conceptus, illustrating the individual variation between conceptuses. The short duration of culture length $(6 \mathrm{~h})$ was used as such filamentous conceptuses do not survive well in vitro. This resulted in a much-reduced exposure time to SILAC media compared to other studies with other types of cultures such as intestinal organoids [30] or bone marrow stromal cells [29]. Similar short incubations have been previously described for BONLAC studies in hippocampal cells (combination of bioorthogonal noncanonical amino acid tagging (BONCAT) and SILAC) [41]. The outcome of these short incubation times will in part depend on the ability of the conceptus to take up those amino acids, and the proportion of light/heavy proteins will also be partially dependent on the protein turnover [42] and their half-life. A longer incubation time using this approach could possibly detect more, but given the limited conceptus survival time under these conditions, this may not be possible.

Three proteins, TKDP1, MERTK, and PARP4, were heavy labelled in the CCM from two or more conceptuses and present in the media from all the conceptuses (Table 3). TKDP1 is produced by the trophoblast with a maximum expression around the beginning of implantation on Day 19 of pregnancy [43] and is likely secreted earlier, e.g., by Day 16 conceptuses in the present study. Other members of the TKFP family $(-2,-3$, and -4$)$ have previously been identified as expressed in Day 16 conceptuses [44]. MERTK is involved in the regulation of inflammation during pregnancy, restraining toll-like receptor (TLR) signaling [45]. This is a similar signaling pathway that can be activated by a Type I interferon, and conceptus-derived MERTK may play a role in enhancing IFN-mediated signaling in the endometrium. The absence of PARP4, or the downregulation of its coding gene, is related to cancer [46-48]. This gene family is related to apoptosis [49] and a potential role for this in Day 16 conceptuses could be regulating cell proliferation. Therefore, the expression of these proteins may contribute to appropriate development of the conceptus and prepare the endometrium for implantation shortly after the pregnancy recognition process.

We did identify a number of other proteins with heavy labelled peptides in CCM from three or more conceptuses, with light labelled versions of these proteins also identified in the CCM from other conceptuses (Table 3) included THO complex subunit 7 homolog, THOC7. Interestingly, THOC7 has been suggested to negatively regulate type I IFN production [50]. Another protein present in the media from five conceptuses (heavy labelled in CCM from three conceptuses) is GPRC5A. This protein belongs to a group of receptors and has been found to be dysregulated in cancer [51] and is a lung cancer suppressor gene [52]. In GPRC5A-knock out mice, prostaglandin E2 synthase (PTGES)/prostaglandin E2 (PGE2) signaling is highly associated with tumorigenesis and metastasis and is related to immune suppression in lung cancer [52]. PGE2 is produced in cattle in response to IFNT to prevent luteolysis and could be related to immune regulation together with GPRC5A. RING finger protein 207 (RNF207) was heavy labelled in five of the CCM and is related to shortened action potential duration in ventricular cardiomyocytes in neonatal rabbits and the knockout of this gene also significantly slows conduction in the ventriculum of the heart of developing zebra fish [53]. Another protein heavy labelled in three CCM was disco interacting protein 2A (DIP2A), which has been previously described as widely expressed in ectoderm-derived tissues in developing embryos and is a potential receptor of FSTL1 and its protective role of cardiomyocytes [54]. This protein, FSTL1, was only detected as light labelled in the CCM from one of the conceptuses in our study. The gene coding for SET domain containing 9 (SETD9), heavy labelled in four CCM and present in media from seven conceptuses, belongs to a greater family, Kmt methyltransferases, that has been found to peak in expression during gastrula stage with a later reduction during embryogenesis in mangrove rivulus fish [55]. Another of the heavy labelled proteins, DExH-box helicase 34 (DHX34), is involved in the complex comprising UPF1 and SMG1, two proteins that are present in the CCM from all the conceptuses as light labelled and that are involved in nonsense-mediated decay [56] and could therefore be important during development although it was 
only detected in three CCM as heavy labelled. Finally, OTU deubiquitinase 6A (OTUD6A) is a protein of a family of cell signaling cascade regulator. Even though its function is still unknown, it is suggested to be associated with p53 [57]. This last protein was heavy labelled in only three CCM. A low turnover rate and a long half-life of some proteins would explain the low proportion of heavy labelled detected proteins $(5.95 \%)$ and may further explain the lack of heavy labelled variants of IFNT in the CCM.

\subsection{Proteins Detected in the ULF-Derived EVs}

This study identified 67 proteins that were exclusively detected in EVs derived from ULF of pregnant heifers. Over-represented GO terms for biological processes were related to different regulatory terms of telomeres, which would be compatible with the morphological and cellular changes that the conceptus is undergoing, i.e., cell division and proliferation.

Three of these EV pregnancy-specific proteins were common between the EVs of Day 16 pregnant heifers in this study and ULF of Day 16 pregnant heifers from previously published results [25]. These are likely to be exclusive to pregnant heifers, even though they were not detected in ULF of Day 16 pregnant heifers in a different study [19]. From those, SLC1A1 is an amino acid transporter, and clathrin heavy chain, CLTC, is related to the maintenance of the kinetochore fibre tension. Those functions are compatible with the stage of development and high cell division rate of the conceptus. The other protein, transketolase (TKT), is involved in the regulation of excess sugar in the pentose phosphate pathway and has been detected in non EV prepared ULF and CCM in other studies. Differences between studies could be in part due to the approaches used. The study by Forde, McGettigan [25] focused on the proteins present in the ULF of pregnant heifers, whereas in the present one, the EVs were isolated from ULF prior to proteomic analysis by mass spectrometry. These results illustrate the differences between the EV cargo compared to the general ULF composition, probably a consequence of the selective nature of the EV cargo loading, highlighting the potential role of EVs in maternal-embryonic communication.

\subsection{Comparison of EVs from ULF vs. CCM Proteins to Determine Those Potentially Involved in IFNT-Independent Communication during the Peri-Implantation Period of Pregnancy in Cattle}

When the proteins in the EVs from ULF from both pregnant and cyclic heifers at Day 16 were compared to those light and heavy labelled in the CCM, all groups shared some proteins (Figure 2). However, no de novo produced heavy labelled proteins were present in the EVs from ULF. This indicates that some of the nontraditionally secreted proteins identified in the CCM are potentially mediating communication between the conceptus and the endometrium, but this is likely EV-mediated. Surprisingly, 10 of the 22 proteins only present in cyclic heifers were also present in CCM from all the conceptuses, but not in the EVs from ULF of pregnant heifers. As only the EVs from ULF were analyzed, there is a possibility for a change in the secretion pathway followed during the estrus cycle and pregnancy in which these proteins are not secreted in EVs, but directly to the ULF during pregnancy, either by the conceptus or the endometrium, they would be lost during sample processing.

\subsection{CCM vs. Previously Published Studies}

The proteins present in the CCM from all the conceptuses, as well as those heavy labelled to any extent, were compared to those present in the CCM after 6 and $24 \mathrm{~h}$ conceptus culture in a previous study [19]. Only three proteins were common to the four groups. One of them, PAG11, is produced by the trophoblast cells, similar to TKDP1. The other protein, DEAD (Asp-Glu-Ala-Asp) box polypeptide 39 isoform 1 (DDX39A) contributes to genome integrity and telomere protection [58], which protects the dividing somatic cells from a progressive loss of telomeric DNA in successive divisions $[59,60]$. We have determined that a limited number of proteins are de novo produced by the Day 16 conceptus following short-term culture in vitro.

The most interesting result is the large cohort of 463 proteins that were present in the CCM of all the conceptuses and also after 6 and $24 \mathrm{~h}$ of culture in the study by Forde, Bazer [19]. These proteins had GO biological terms related to sensory and chemical perception, telomere regulation and 
chaperones. The most relevant thing in relation to this group of proteins is that their transcripts were not detected in the endometrium of Day 16 pregnant heifers in a previous study [9]. This indicates that the proteins observed are likely being produced by the conceptuses and, if detected in the ULF, they could be attributable to the conceptus and associated with bilateral communication during pregnancy recognition. Furthermore, they were all light labelled, and therefore produced prior to in vitro culture and not in response to the in vitro environment. Twenty of these proteins were also detected in EVs from ULF of pregnant heifers in the present study (Figure 4), which confirms the EV secretory activity of the conceptus along with the identification of EV markers (HSPA70) among the light labelled proteins in the CCM. Of the 463 proteins in the set, 39 were also detected in EVs from CCM from ovine conceptuses at a similar stage of development, Day 14, after $24 \mathrm{~h}$ of in vitro culture [38], eight of which are subunits of the proteasome. Further research will be required to investigate whether these proteins could be potentially conserved between ruminant species and be involved in establishment of pregnancy due to the stage of development at which they have been identified.

In conclusion, we used a SILAC-based approach to investigate the proteins secreted in vitro by Day 16 conceptuses to gain insight into those proteins that are conceptus-derived and may mediate communication during the pregnancy recognition process. We identified a group of 463 proteins in the CCM in the present study and after 6 and $24 \mathrm{~h}$ in vitro culture in a previous study [19] that lack transcripts in the endometrium [9] and potentially mediate communication in vivo. Twenty proteins were present only in the EVs from the ULF of Day 16 pregnant heifers and in the CCM from all the conceptuses as well as in previous studies after 6 and $24 \mathrm{~h}$ culture [19]. Furthermore, 39 proteins present in CCM in the present and previous studies [19] have been described as present in EVs from CCM of ovine conceptuses at a similar stage of development [38]. We propose that these are involved in molecular communication between the conceptus and endometrium in early pregnancy.

\section{Materials and Methods}

All experimental procedures involving animals were sanctioned by the Animal Research Ethics Committee of University College Dublin and were licensed by the Health Products Regulatory Authority, Ireland, in accordance with Statutory Instrument No. 543 of 2012 under Directive 2010/63/EU on the Protection of Animals used for Scientific Purposes. Unless otherwise stated all chemicals were sourced from Sigma Aldrich, Dublin, Ireland.

\subsection{Experiment 1: Identification of De Novo Synthesised Proteins Produced by Day 16 Conceptuses Following Short-Term Culture In Vitro}

\subsubsection{Animal Synchronization and Sample Collection}

The estrous cycles of cross-bred beef heifers were synchronized using a progesterone-releasing intravaginal device (PRID E, $1.55 \mathrm{~g}$ progesterone; Ceva Santé Animale, Libourne, France) inserted into the vagina for eight days. On the day of PRID insertion all heifers received a $2 \mathrm{~mL}$ intramuscular (i.m.) injection of an analogue of gonadotrophin releasing hormone (Ovarelin; Ceva Santé Animale, Libourne, France, equivalent to $100 \mu \mathrm{g}$ gonadorelin) and one day prior to PRID E removal all heifers received a $5 \mathrm{~mL}$ i.m. injection of a prostaglandin F2 $\alpha$ analogue (Enzaprost, Ceva Santé Animal, Libourne, France, equivalent to $25 \mathrm{mg}$ dinoprost). All heifers were monitored for standing estrus and were artificially inseminated $(n=10)$ twice, $12 \mathrm{~h}$ apart, with semen from a bull of proven fertility. All heifers were slaughtered on Day 16 of the estrous cycle/ early pregnancy (estrus = Day 1) at a commercial abattoir. After slaughter, the reproductive tracts were recovered and transported at room temperature for approximately $40 \mathrm{~min}$ to the laboratory where the uterine horn ipsilateral to the CL was noted and both uterine horns were flushed separately with $10 \mathrm{~mL}$ of PBS (pH 7.2). The volume of recovered ULF was noted and only those with an appropriately elongated conceptus were further processed. Conceptuses $(n=8)$ were individually placed in a six-well dish with $10 \mathrm{~mL}$ arginine- and lysine-depleted culture medium (SILAC DMEM, Thermo Fisher, UK) supplemented with heavy labelled arginine (L-arginine 
13C6, Thermo Fisher, UK) and lysine (L-lysine 13C6, Thermo Fisher, UK) and were cultured for $6 \mathrm{~h}$ at $38.5^{\circ} \mathrm{C}, 5 \% \mathrm{CO}_{2}$ and $5 \% \mathrm{O}_{2}$. At one-hour intervals $500 \mu \mathrm{L}$ of conceptus conditioned medium (CCM) was removed and after $6 \mathrm{~h}$ of culture, media was clarified by centrifugation at $3000 \times g$ for $15 \mathrm{~min}$ at $4{ }^{\circ} \mathrm{C}$. The supernatant was recovered into a new RNase DNase free tube and snap frozen in liquid nitrogen and stored at $-80{ }^{\circ} \mathrm{C}$ prior to processing. Contemporaneous blanks (medium without a conceptus) were also cultured in parallel and processed as above. Only the $6 \mathrm{~h}$ time-point recovered media was used for the present study.

\subsubsection{Analysis of Protein Content of Conceptus-Conditioned Medium (CCM)}

Samples from the $6 \mathrm{~h}$ CCM time-point were concentrated to approximately $50 \mu \mathrm{l}$ using Microcon centrifugal filter units with a $3 \mathrm{kDa}$ cut-off (Merck Millipore, Burlington, MA, USA). Twenty-five $\mu \mathrm{L}$ of $3 \times$ laemmli buffer was then added and the samples boiled for $15 \mathrm{~min}$ prior to loading onto a $10 \%$ SDS-polyacrylamide gel. The gel was resolved at $125 \mathrm{~V}$ until the dye front had entered the separating gel and then at $200 \mathrm{~V}$ until the dye front had moved $3 \mathrm{~cm}$ into the separating gel. The gel was briefly stained in $0.1 \%$ Coomassie brilliant blue R in 50\% methanol and then destained in 50\% methanol; $7 \%$ acetic acid. To ensure complete removal of Coomassie and to remove SDS, the gel slices were then subjected to four cycles of the following destaining process: Incubation in $300 \mu \mathrm{L} 50 \mathrm{mM}$ ammonium bicarbonate for $10 \mathrm{~min}$ followed by the addition of $600 \mu \mathrm{L}$ acetonitrile and incubation for a further $45 \mathrm{~min}$. After the final destain step, the gel slices were incubated in water for $30 \mathrm{~min}$, cut into $1 \mathrm{~mm}$ square pieces and subjected to in-gel tryptic digestion using a DigestPro automated digestion unit (Intavis, Cologne, Germany). The resulting peptides were fractionated using an Ultimate 3000 nano-LC system in line with an Orbitrap Fusion Tribrid mass spectrometer (Thermo Scientific, Waltham, MA, USA). In brief, peptides in $1 \%$ (vol/vol) formic acid were injected onto an Acclaim PepMap C18 nano-trap column (Thermo Scientific, Waltham, MA, USA). After washing with $0.5 \%$ ( vol/vol) acetonitrile $0.1 \%$ (vol/vol) formic acid, peptides were resolved on a $250 \mathrm{~mm} \times 75 \mu \mathrm{m}$ Acclaim PepMap C18 reverse phase analytical column (Thermo Scientific, Waltham, MA, USA) over a $150 \mathrm{~min}$ organic gradient, using seven gradient segments $(1 \%-6 \%$ solvent B over $1 \mathrm{~min}, 6 \%-15 \%$ B over $58 \mathrm{~min}$, $15 \%-32 \%$ B over $58 \mathrm{~min}, 32 \%-40 \%$ B over $5 \mathrm{~min}, 40 \%-90 \%$ B over $1 \mathrm{~min}$, held at $90 \%$ B for $6 \mathrm{~min}$, and then reduced to $1 \%$ B over $1 \mathrm{~min}$ ) with a flow rate of $300 \mathrm{NL} / \mathrm{min}$. Solvent A was $0.1 \%$ formic acid and Solvent $\mathrm{B}$ was $80 \%$ aqueous acetonitrile in $0.1 \%$ formic acid. Peptides were ionized by nanoelectrospray ionization at $2.2 \mathrm{kV}$ using a stainless-steel emitter with an internal diameter of $30 \mu \mathrm{m}$ (Thermo Scientific, Waltham, MA, USA) and a capillary temperature of $250{ }^{\circ} \mathrm{C}$.

All spectra were acquired using an Orbitrap Fusion Tribrid mass spectrometer controlled by Xcalibur 3.0 software (Thermo Scientific, Waltham, MA, USA) and operated in data-dependent acquisition mode. FTMS1 spectra were collected at a resolution of 120,000 over a scan range (m/z) of 350-1550, with an automatic gain control (AGC) target of 400,000 and a max injection time of $100 \mathrm{~ms}$. Precursors were filtered according to charge state (to include charge states 2-7), with monoisotopic peak determination set to peptide and using an intensity range from $5 \times 10^{3}$ to $1 \times 10^{20}$. Previously interrogated precursors were excluded using a dynamic window $(40 \mathrm{~s} \pm 10 \mathrm{ppm})$. The MS2 precursors were isolated with a quadrupole mass filter set to a width of $1.6 \mathrm{~m} / \mathrm{z}$. ITMS2 spectra were collected with an AGC target of 5000, max injection time of $50 \mathrm{~ms}$ and HCD collision energy of $35 \%$.

\subsubsection{Data Analysis}

The raw proteomic mass spectrometry data files were processed using Proteome Discoverer software v1.4 (Thermo Scientific, Waltham, MA, USA) and searched against the UniProt Bos taurus database (downloaded March 2019; 32,159 entries) using the SEQUEST algorithm. Peptide precursor mass tolerance was set at $10 \mathrm{ppm}$, and MS/MS tolerance was set at $0.6 \mathrm{Da}$. Search criteria included carbamidomethylation of cysteine $(+57.0214)$ as a fixed modification and oxidation of methionine $(+15.9949)$ and appropriate SILAC labels $\left({ }^{13} \mathrm{C}_{6}\right.$-Arg and ${ }^{13} \mathrm{C}_{6}$-Lys $)$ as variable modifications. Searches were performed with full tryptic digestion and a maximum of two missed cleavage events were 
allowed. The reverse database search option was enabled and all peptide data was filtered to satisfy false discovery rate (FDR) of $5 \%$.

Proteins detected in any of the three media-only samples (contemporaneous blanks) had their Uniprot IDs combined with "cat $\mid$ sort - $\mathrm{u}$ ", and then removed from each individual conceptus protein list with "diff-y | grep -P '[> $>\mid]^{\prime}$ " Unix/Bash commands. A Venn Diagram-like textual table was generated using the BASH pipeline to allow a searchable data base containing shared or specific proteins from $n=8 \mathrm{CCM}$ data sets, as well as retrieve both "Scores" and "Heavy/Light Variability" metrics from any selected list of target proteins. The proteins detected in CCM were submitted for pathway analysis on DAVID (DAVID Bioinformatics Resources 6.8, NIAD, https://david.ncifcrf.gov/) [33,34]. Three different analyses were performed. The first analysis included all the proteins present in the CCM from all eight conceptuses, independent of the presence of peptide fragments containing heavy labelled amino acids. A second analysis included all proteins with a peptide fragment containing a heavy label in CCM from at least two different conceptuses. Finally, the last analysis included all proteins that were heavy labelled in the media from at least one conceptus but present in the media from all conceptuses (i.e., heavy labelled in the media from one conceptus and light labelled in the media from seven conceptuses). The same protein groups were also analyzed for GO terms with the GO enrichment analysis tool (http://geneontology.org/) [35-37]. Comparisons between studies and groups and Venn diagrams were performed with the tool Venny (version 2.1, CNB-CSIC, Madrid, Spain; https://bioinfogp.cnb.csic.es/tools/venny/) [61].

4.2. Experiment 2: Proteomic Component of Extracellular Vesicles Obtained from the Uterine Luminal Fluid of Cyclic and Pregnant Heifers on Day 16

\subsubsection{Animal Synchronization and Sample Collection}

The estrous cycles of cross-bred beef heifers were synchronized as described above. Heifers were monitored for standing estrus and randomly assigned to either a cyclic control $(n=7)$ or an artificially inseminated group $(n=11)$. All heifers were slaughtered on Day 16 of the estrous cycle/early pregnancy (estrus $=$ Day 0 ) at a commercial abattoir. After slaughter the reproductive tracts were recovered and kept on ice prior to processing for sample collection at the abattoir. Uterine horns ipsilateral and contralateral to the CL were flushed separately with $10 \mathrm{~mL}$ of PBS (pH 7.2) as described above. The volume of recovered fluid was noted and, in the inseminated group, only those with an appropriately elongated conceptus were further processed. The recovered fluid was clarified by centrifugation at $3000 \times g$ for $15 \mathrm{~min}$ at $4{ }^{\circ} \mathrm{C}$. The supernatant was recovered into a new RNase DNase free tube, gently inverted 10 times to ensure homogeneity, aliquoted into $1 \mathrm{~mL}$ aliquots and snap frozen in liquid nitrogen and stored at $-80^{\circ} \mathrm{C}$ prior to processing for extracellular vesicle (EV) analyses.

\subsubsection{Extraction of Extracellular Vesicles from Uterine Luminal Fluid and Proteomic Analysis}

The EV isolation protocol was as described by Burns, Brooks [21]. The ULF was clarified and filtered with a $0.22 \mu \mathrm{m}$ PVDF syringe filter (EMD Millipore, Billerica, MA, USA) to remove large microvesicles. EVs were isolated from by the addition of $200 \mu \mathrm{L}$ ExoQuick-TC (System Biosciences, Palo Alto, CA, USA) precipitation solution per $\mathrm{mL}$ of filtered ULF. Tubes were incubated overnight at $4{ }^{\circ} \mathrm{C}$ and then centrifuged at $15,000 \times \mathrm{g}$ for $30 \mathrm{~min}$ at $4{ }^{\circ} \mathrm{C}$ to recover EVs. Pellets were suspended in sterile PBS and evaluated using a NanoSight LM-10 instrument (NanoSight, Amesbury, UK) calibrated with $100 \mathrm{~nm}$ polystyrene beads (Polysciences, Warrington, PA, USA). Videos were captured (camera level 13-14, syringe pump speed 30 , temperature control setting $25^{\circ} \mathrm{C}$ ) using the standard measurement protocol of five $60 \mathrm{~s}$ videos followed by processing with NTA software (NanoSight) to track each visible particle. The Stokes-Einstein equation was employed by the software to determine the size distribution and number of particles (concentration) within each sample. The protein content of these EVs was analysed by mass spectrometry by the Charles W. Gehrke Proteomics Center at the University of Missouri as previously described [5]. 
Supplementary Materials: Supplementary materials can be found at http://www.mdpi.com/1422-0067/21/8/2870/s1.

Author Contributions: Conceptualization, N.F., P.L., and T.E.S.; methodology, H.T., J.M.S., B.F.-F., G.W.B. N.F.; software, G.W.B., E.J.R.V.; validation, and formal analysis, H.T., J.M.S., B.F.-F., G.W.B., E.J.R.V., I.M.E.; data curation, G.W.B., I.M.E., E.J.R.V.; writing—original draft preparation, N.F., I.M.E.; writing—review and editing, all authors; supervision, N.F., P.L., T.E.S.; project administration, N.F.; funding acquisition, N.F. and P.L. All authors have read and agreed to the published version of the manuscript.

Funding: This work is supported by research grants from the BBSRC (BB/R017522/1), the United Nations IAEA technical research contract under CRP D3.10.28 to NF. PL was supported by Science Foundation Ireland (13/IA/1983). GB is currently supported by grant number T32HD087166.

Acknowledgments: We acknowledge the assistance of Michael McDonald with the animal work and the University of Bristol's protein core facility for the analysis of SILAC-labelled samples.

Conflicts of Interest: The authors declare no conflict of interest.

\section{References}

1. Maillo, V.; Gaora, P.Ó.; Forde, N.; Besenfelder, U.; Havlicek, V.; Burns, G.W.; Spencer, T.E.; Gutierrez-Adan, A.; Lonergan, P.; Rizos, D. Oviduct-Embryo Interactions in Cattle: Two-Way Traffic or a One-Way Street? Biol. Reprod. 2015, 92, 144. [CrossRef] [PubMed]

2. Rizos, D.; Maillo, V.; Lonergan, P. Role of the oviduct and oviduct-derived products in ruminant embryo development. Anim. Reprod. 2016, 13, 160-167. [CrossRef]

3. Cordova, A.; Perreau, C.; Uzbekova, S.; Ponsart, C.; Locatelli, Y.; Mermillod, P. Development rate and gene expression of IVP bovine embryos cocultured with bovine oviduct epithelial cells at early or late stage of preimplantation development. Theriogenology 2014, 81, 1163-1173. [CrossRef] [PubMed]

4. Rizos, D.; Ward, F.; Duffy PA, T.; Boland, M.P.; Lonergan, P. Consequences of bovine oocyte maturation, fertilization or early embryo development In Vitro versus In Vivo: Implications for blastocyst yield and blastocyst quality. Mol. Reprod. Dev. 2002, 61, 234-248. [CrossRef]

5. Sponchiado, M.; Gomes, N.S.; Fontes, P.K.; Martins, T.; del Collado, M.; de Assumpcao Pastore, A.; Pugliesi, G.; Nogueira, M.F.G.; Binelli, M. Pre-hatching embryo-dependent and -independent programming of endometrial function in cattle. PLoS ONE 2017, 12, e0175954. [CrossRef] [PubMed]

6. Passaro, C.; Tutt, D.; Mathew, D.J.; Sanchez, J.M.; Browne, J.A.; Boe-Hansen, G.B.; Fair, T.; Lonergan, P. Blastocyst-induced changes in the bovine endometrial transcriptome. Reproduction 2018, 156, $219-229$. [CrossRef]

7. Passaro, C.; Tutt, D.; Bagés-Arnal, S.; Maicas, C.; Laguna-Barraza, R.; Gutierrez-Adan, A.; Browne, J.A.; Rath, D.; Behura, S.K.; Spencer, T.E.; et al. Global transcriptomic response of bovine endometrium to blastocyst-stage embryos. Reproduction 2019, 158, 223-235. [CrossRef]

8. Spencer, T.E.; Forde, N.; Dorniak, P.; Hansen, T.R.; Romero, J.J.; Lonergan, P. Conceptus-derived prostaglandins regulate gene expression in the endometrium prior to pregnancy recognition in ruminants. Reproduction 2013, 146, 377-387. [CrossRef]

9. Forde, N.; Duffy, G.B.; McGettigan, P.A.; Browne, J.A.; Mehta, J.P.; Kelly, A.K.; Mansouri-Attia, N.; Sandra, O.; Loftus, B.J.; Crowe, M.A.; et al. Evidence for an early endometrial response to pregnancy in cattle: Both dependent upon and independent of interferon tau. Physiol. Genom. 2012, 44, 799-810. [CrossRef]

10. Forde, N.; Carter, F.; Spencer, T.E.; Bazer, F.W.; Sandra, O.; Mansouri-Attia, N.; Okumu, L.A.; McGettigan, P.A.; Mehta, J.P.; McBride, R.; et al. Conceptus-induced changes in the endometrial transcriptome: How soon does the cow know she is pregnant? Biol. Reprod. 2011, 85, 144-156. [CrossRef]

11. Bauersachs, S.; Ulbrich, S.E.; Gross, K.; Schmidt, S.E.M.; Meyer, H.H.D.; Wenigerkind, H.; Vermehren, M.; Sinowatz, F.; Blum, H.; Wolf, E. Embryo-induced transcriptome changes in bovine endometrium reveal species-specific and common molecular markers of uterine receptivity. Reproduction 2006, 132, 319. [CrossRef] [PubMed]

12. Bauersachs, S.; Ulbrich, S.E.; Reichenbach, H.D.; Reichenbach, M.; Büttner, M.; Meyer, H.H.D.; Spencer, T.E.; Minten, M.; Sax, G.; Winter, G.; et al. Comparison of the Effects of Early Pregnancy with Human Interferon, Alpha 2 (IFNA2), on Gene Expression in Bovine Endometrium. Biol. Reprod. 2012, 86. [CrossRef] [PubMed]

13. Gifford, C.A.; Racicot, K.; Clark, D.S.; Austin, K.J.; Hansen, T.R.; Lucy, M.C.; Davies, C.J.; Ott, T.L. Regulation of Interferon-Stimulated Genes in Peripheral Blood Leukocytes in Pregnant and Bred, Nonpregnant Dairy Cows. J. Dairy Sci. 2007, 90, 274-280. [CrossRef] 
14. Pugliesi, G.; Miagawa, B.T.; Paiva, Y.N.; França, M.R.; Silva, L.A.; Binelli, M. Conceptus-Induced Changes in the Gene Expression of Blood Immune Cells and the Ultrasound-Accessed Luteal Function in Beef Cattle: How Early Can We Detect Pregnancy? Biol. Reprod. 2014, 91. [CrossRef]

15. Kamat, M.M.; Vasudevan, S.; Maalouf, S.A.; Townson, D.H.; Pate, J.L.; Ott, T.L. Changes in Myeloid Lineage Cells in the Uterus and Peripheral Blood of Dairy Heifers During Early Pregnancy. Biol. Reprod. 2016, 95. [CrossRef]

16. Vasudevan, S.; Kamat, M.M.; Walusimbi, S.S.; Pate, J.L.; Ott, T.L. Effects of early pregnancy on uterine lymphocytes and endometrial expression of immune-regulatory molecules in dairy heifers. Biol. Reprod. 2017, 97, 104-118. [CrossRef]

17. Sanchez, J.M.; Mathew, D.J.; Behura, S.K.; Passaro, C.; Charpigny, G.; Butler, S.T.; Spencer, T.E.; Lonergan, P. Bovine endometrium responds differentially to age-matched short and long conceptusesdagger. Biol. Reprod. 2019, 101, 26-39. [CrossRef]

18. Mathew, D.J.; Sánchez, J.M.; Passaro, C.; Charpigny, G.; Behura, S.K.; Spencer, T.E.; Lonergan, P. Interferon tau-dependent and independent effects of the bovine conceptus on the endometrial transcriptomedagger. Biol. Reprod. 2019, 100, 365-380. [CrossRef]

19. Forde, N.; Bazer, F.W.; Spencer, T.E.; Lonergan, P. 'Conceptualizing' the Endometrium: Identification of Conceptus-Derived Proteins During Early Pregnancy in Cattle. Biol. Reprod. 2015, 92, 156. [CrossRef]

20. Masters, R.A.; Roberts, R.M.; Lewis, G.S.; Thatcher, W.W.; Bazer, F.W.; Godkin, J.D. High molecular weight glycoproteins released by expanding, pre-attachment sheep, pig and cow blastocysts in culture. Reproduction 1982, 66, 571. [CrossRef]

21. Burns, G.W.; Brooks, K.E.; O’Neil, E.V.; Hagen, D.E.; Behura, S.K.; Spencer, T.E. Progesterone effects on extracellular vesicles in the sheep uterus. Biol. Reprod. 2018, 98, 612-622. [CrossRef] [PubMed]

22. Ruiz-González, I.; Xu, J.; Wang, X.; Burghardt, R.C.; Dunlap, K.A.; Bazer, F.W. Exosomes, endogenous retroviruses and toll-like receptors: Pregnancy recognition in ewes. Reproduction 2015, 149, 281. [CrossRef] [PubMed]

23. Kusama, K.; Nakamura, K.; Bai, R.; Nagaoka, K.; Sakurai, T.; Imakawa, K. Intrauterine exosomes are required for bovine conceptus implantation. Biochem. Biophys. Res. Commun. 2018, 495, 1370-1375. [CrossRef] [PubMed]

24. Taqi, M.O.; Saeed-Zidane, M.; Gebremedhn, S.; Salilew-Wondim, D.; Khdrawy, O.; Rings, F.; Neuhoff, C.; Hoelker, M.; Schellander, K.; Tesfaye, D. Sexual dimorphic expression and release of transcription factors in bovine embryos exposed to oxidative stress. Mol. Reprod. Dev. 2019, 86, 2005-2019. [CrossRef] [PubMed]

25. Forde, N.; McGettigan, P.A.; Mehta, J.P.; O'Hara, L.; Mamo, S.; Bazer, F.W.; Spencer, T.E.; Lonergan, P. Proteomic analysis of uterine fluid during the pre-implantation period of pregnancy in cattle. Reproduction 2014, 147, 575-587. [CrossRef] [PubMed]

26. Alexopoulos, N.I.; Vajta, G.; Maddox-Hyttel, P.; French, A.J.; Trounson, A.O. Stereomicroscopic and histological examination of bovine embryos following extended in vitro culture. Reprod. Fertil. Dev. 2005, 17, 799-808. [CrossRef]

27. Brandao, D.O.; Maddox-Hyttel, P.; Løvendahl, P.; Rumpf, R.; Stringfellow, D.; Callesen, H. Post hatching development: A novel system for extended in vitro culture of bovine embryos. Biol. Reprod. 2004, 71, 2048-2055. [CrossRef]

28. Deng, J.; Erdjument-Bromage, H.; Neubert, T.A. Quantitative Comparison of Proteomes Using SILAC. Curr. Protoc. Protein Sci. 2019, 95, e74. [CrossRef]

29. Liu, R.; Wang, Y.; Li, B.; Wang, H.; Guan, F.; Tan, Z.; Li, X. Screening differentially expressed proteins from co-cultured hematopoietic cells and bone marrow-derived stromal cells by quantitative proteomics (SILAC) method. Clin. Proteom. 2019, 16, 32. [CrossRef]

30. Gonneaud, A.; Jones, C.; Turgeon, N.; Lévesque, D.; Asselin, C.; Boudreau, F.; Boisvert, F.M. A SILAC-Based Method for Quantitative Proteomic Analysis of Intestinal Organoids. Sci. Rep. 2016, 6, 38195. [CrossRef]

31. Bogenhagen, D.F.; Haley, J.D. Pulse-chase SILAC-based analyses reveal selective over-synthesis and rapid turnover of mitochondrial protein components of respiratory complexes. J. Biol. Chem. 2020, 295, 2544-2554. [CrossRef] [PubMed]

32. Beati, H.; Langlands, A.; ten Have, S.; Müller, H.A.J. SILAC-based quantitative proteomic analysis of Drosophila gastrula stage embryos mutant for fibroblast growth factor signalling. Fly 2019, 1-19. [CrossRef] [PubMed] 
33. Huang, D.W.; BSherman, T.; Lempicki, R.A. Bioinformatics enrichment tools: Paths toward the comprehensive functional analysis of large gene lists. Nucleic Acids Res. 2009, 37, 1-13. [CrossRef] [PubMed]

34. Huang, D.W.; Sherman, B.T.; Lempicki, R.A. Systematic and integrative analysis of large gene lists using DAVID bioinformatics resources. Nat. Protoc. 2009, 4, 44-57. [CrossRef] [PubMed]

35. Ashburner, M.; Ball, C.A.; Blake, J.A.; Botstein, D.; Butler, H.; Cherry, J.M.; Davis, A.P.; Dolinski, K.; Dwight, S.S.; Eppig, J.T.; et al. Gene ontology: Tool for the unification of biology. Nat. Genet. 2000, 25, 25-29. [CrossRef]

36. Mi, H.; Muruganujan, A.; Ebert, D.; Huang, X.; Thomas, P.D. PANTHER version 14: More genomes, a new PANTER GO-slim and improvements in enrichment analysis tools. Nucleic Acids Res. 2019, 47, D419-D426. [CrossRef]

37. The Gene Ontology Consortium. The Gene Ontology Resource: 20 years and still GOing strong. Nucleic Acids Res. 2019, 47, D330-D338. [CrossRef]

38. Burns, G.W.; Brooks, K.E.; Spencer, T.E. Extracellular Vesicles Originate from the Conceptus and Uterus During Early Pregnancy in Sheep. Biol. Reprod. 2016, 94. [CrossRef]

39. Pluchino, S.; Smith, J.A. Explicating Exosomes: Reclassifying the Rising Stars of Intercellular Communication. Cell 2019, 177, 225-227. [CrossRef]

40. Jeppesen, D.K.; Fenix, A.M.; Franklin, J.L.; Higginbotham, J.N.; Zhang, Q.; Zimmerman, L.J.; Liebler, D.C.; Ping, J.; Liu, Q.; Evans, R.; et al. Reassessment of Exosome Composition. Cell 2019, 177, 428-445.e18. [CrossRef]

41. Bowling, H.; Bhattacharya, A.; Zhang, G.; Lebowitz, J.Z.; Alam, D.; Smith, P.T.; Kirshenbaum, K.; Neubert, T.A.; Vogel, C.; Chao, M.V.; et al. BONLAC: A combinatorial proteomic technique to measure stimulus-induced translational profiles in brain slices. Neuropharmacology 2016, 100, 76-89. [CrossRef] [PubMed]

42. Basisty, N.; Meyer, J.G.; Schilling, B. Protein Turnover in Aging and Longevity. Proteomics 2018, 18, e1700108. [CrossRef] [PubMed]

43. MacLean, J.A., 2nd; Chakrabarty, A.; Xie, S.; Bixby, J.A.; Roberts, R.M.; Green, J.A. Family of Kunitz proteins from trophoblast: Expression of the trophoblast Kunitz domain proteins (TKDP) in cattle and sheep. Mol. Reprod. Dev. 2003, 65, 30-40. [CrossRef] [PubMed]

44. Mamo, S.; Mehta, J.P.; Forde, N.; McGettigan, P.; Lonergan, P. Conceptus-endometrium crosstalk during maternal recognition of pregnancy in cattle. Biol. Reprod. 2012, 87, 6. [CrossRef] [PubMed]

45. Cross, S.N.; Potter, J.A.; Aldo, P.; Kwon, J.Y.; Pitruzzello, M.; Tong, M.; Guller, S.; Rothlin, C.V.; Mor, G.; Abrahams, V.M. Viral Infection Sensitizes Human Fetal Membranes to Bacterial Lipopolysaccharide by MERTK Inhibition and Inflammasome Activation. J. Immunol. 2017, 199, 2885-2895. [CrossRef]

46. Ikeda, Y.; Kiyotani, K.; Yew, P.Y.; Kato, T.; Tamura, K.; Yap, K.L.; Nielsen, S.M.; Mester, J.L.; Eng, C.; Nakamura, Y.; et al. Germline PARP4 mutations in patients with primary thyroid and breast cancers. Endocr. Relat. Cancer 2016, 23, 171-179. [CrossRef]

47. Prawira, A.; Munusamy, P.; Yuan, J.; Chan, C.H.T.; Koh, G.L.; Shuen, T.W.H.; Hu, J.; Yap, Y.S.; Tan, M.H.; Ang, P.; et al. Assessment of PARP4 as a candidate breast cancer susceptibility gene. Breast Cancer Res. Treat. 2019, 177, 145-153. [CrossRef]

48. Cirello, V.; Colombo, C.; Pogliaghi, G.; Proverbio, M.C.; Rossi, S.; Mussani, E.; Tosi, D.; Bulfamante, G.; Bonoldi, E.; Gherardi, G.; et al. Genetic variants of PARP4 gene and PARP4P2 pseudogene in patients with multiple primary tumors including thyroid cancer. Mutat. Res. Fundam. Mol. Mech. Mutagenes. 2019, 816-818, 111672. [CrossRef]

49. Oliver, F.J.; de la Rubia, G.; Rolli, V.; Ruiz-Ruiz, M.C.; de Murcia, G.; Ménissier-de Murcia, J. Importance of Poly(ADP-ribose) Polymerase and Its Cleavage in Apoptosis: Lesson from an uncleavable mutant. J. Biol. Chem. 1998, 273, 33533-33539. [CrossRef]

50. He, T.-S.; Xie, T.; Li, J.; Yang, Y.X.; Li, C.; Wang, W.; Cao, L.; Rao, H.; Ju, C.; Xu, L.G. THO Complex Subunit 7 Homolog Negatively Regulates Cellular Antiviral Response against RNA Viruses by Targeting TBK1. Viruses 2019, 11, 158. [CrossRef]

51. Jiang, X.; Xu, X.; Wu, M.; Guan, Z.; Su, X.; Chen, S.; Wang, H.; Teng, L. GPRC5A: An Emerging Biomarker in Human Cancer. BioMed Res. Int. 2018, 2018, 1823726. [CrossRef] [PubMed]

52. Wang, T.; Jing, B.; Xu, D.; Liao, Y.; Song, H.; Sun, B.; Guo, W.; Xu, J.; Li, K.; Hu, M.; et al. PTGES/PGE2 signaling links immunosuppression and lung metastasis in Gprc5a-knockout mouse model. Oncogene 2020, 39, 3179-3194. [CrossRef] [PubMed] 
53. Roder, K.; Werdich, A.A.; Li, W.; Liu, M.; Kim, T.Y.; Organ-Darling, L.E.; Moshal, K.S.; Hwang, J.M.; Lu, Y.; Choi, B.-R.; et al. RING finger protein RNF207, a novel regulator of cardiac excitation. J. Biol. Chem. 2014, 289, 33730-33740. [CrossRef]

54. Zhang, L.; Mabwi, H.A.; Palange, N.J.; Jia, R.; Ma, J.; Bah, F.B.; Sah, R.K.; Li, D.; Wang, D.; Bah, F.B.M.; et al. Expression Patterns and Potential Biological Roles of Dip2a. PLoS ONE 2015, 10, e0143284. [CrossRef] [PubMed]

55. Fellous, A.; Earley, R.L.; Silvestre, F. The Kdm/Kmt gene families in the self-fertilizing mangrove rivulus fish, Kryptolebias marmoratus, suggest involvement of histone methylation machinery in development and reproduction. Gene 2019, 687, 173-187. [CrossRef] [PubMed]

56. Melero, R.; Hug, N.; López-Perrote, A.; Yamashita, A.; Cáceres, J.F.; Llorca, O. The RNA helicase DHX34 functions as a scaffold for SMG1-mediated UPF1 phosphorylation. Nat. Commun. 2016, 7, 10585. [CrossRef]

57. Kim, S.Y.; Kwon, S.K.; Lee, S.Y.; Baek, K.H. Ubiquitin-specific peptidase 5 and ovarian tumor deubiquitinase 6A are differentially expressed in p53+/+ and p53-/-HCT116 cells. Int. J. Oncol. 2018, 52, 1705-1714.

58. Yoo, H.H.; Chung, I.K. Requirement of DDX39 DEAD box RNA helicase for genome integrity and telomere protection. Aging Cell 2011, 10, 557-571. [CrossRef]

59. Lingner, J.; Cooper, J.; Cech, T. Telomerase and DNA end replication: No longer a lagging strand problem? Science 1995, 269, 1533-1534. [CrossRef]

60. Cerone, M.A.; Autexier, C.; Londono-Vallejo, J.A.; Bacchetti, S. A human cell line that maintains telomeres in the absence of telomerase and of key markers of ALT. Oncogene 2005, 24, 7893-7901. [CrossRef]

61. Venny. An Interactive Tool for Comparing Lists with Venn's Diagrams. 2007-2015. Available online: https://bioinfogp.cnb.csic.es/tools/venny/index.html (accessed on 17 April 2020).

(C) 2020 by the authors. Licensee MDPI, Basel, Switzerland. This article is an open access article distributed under the terms and conditions of the Creative Commons Attribution (CC BY) license (http://creativecommons.org/licenses/by/4.0/). 